\title{
Physico-Chemical Properties of Chromatin and Induction of Ploidy in Sugarcane
}

\author{
Seehy M. A. ${ }^{1}$, Ghonema M. A. ${ }^{2}$, Saleh M. S. ${ }^{2}$ and Badawy O. M. ${ }^{2}$
}

\begin{abstract}
This work was carried out at Subbhia experimental station for sugar crops. The present investigation aims at inducing polyploidy in sugar cane (Saccharum officinarum) and to investigate its agronomic traits. Colchicine was used to produce poly ploidy from three cultivars. These cultivars are (C9 G.T. 54-9, PH 8013 and NCO 310). Buds were treated with $0.05 \%$ colchicine solution. Treated segments were allowed to germinate until a shoot system length of $40 \mathrm{~cm}$ had reached. Plants were then transferred and allowed to grow in the yield. The growing plants were examined for polyploidy firstly by Guard cells of Stomata, Chloroplasts, DNA content in leaves, and chromosomes from adventitious roots initiated at the laboratory. Physico-chemical properties for chromatins and deproteinized DNA were estimated. Total soluble solids (T.S.S); plant height and plant diameter were estimated. The obtained results would be summarized as follows: The present studies aimed to produce polyploidy in cultivar C9. The obtained results showed that the average of polyploidy was found to be $9 \%$ for C9 and $4 \%$ for PH 8013. Regarding chemical composition and melting temperatures of chromatins different ratios were obtained reflecting differential transcriptional activities. However, active and repressed fractions of chromatin were estimated. With respect to the evaluated agronomic characteristics different values were observed.
\end{abstract}

\section{INTRODUCTION}

It is well known that genetic improvement of crop plants depends on the availability of desirable agronomical characters to begin with. In addition, it needs an appropriate screening method to detect these desirable characters. The scientific achievements during the last two decades in the field of biotechnology, suggest that it is now the time to apply the existing knowledge for practical problems in agriculture, specially the production and the isolation of new genetic variability in higher plants. Among these new developments, in vitro plant culture techniques (meristem, embryo, cali, cells and protoplasts) offer a great potential for the improvement of crop plants (Bourgin, 1983; Maliga, 1984).

All over the world, the increase of sugar production through the genetic improvement of the two most important sugar crops, i.e. sugar cane (Saccharum

\footnotetext{
${ }^{1}$ Department of Genetics, Faculty of Agriculture, Alexandria University.

${ }^{2}$ Genetic and Breeding Department, Sugar Crops Research Institute,

Agricultural Research Center.

Received October 7, 2012, Accepted December 28, 2012.
}

officinarum L.) and sugar beet (Beta vulgaris L.), is an ongoing process, since more than 2000 years. In Egypt sugar cane is considered among the most important industrial converting crops. It is the main source of sugar industry and the sole source for molasses industry. Sugar cane is cultivated in about 270,000 fedan producing about 1,100,000 ton of sugar annually (Sugar Annual Report of Egypt, USDA-2012). In Egypt, although sugar beet crop is a supplement for sugar industry, its byproducts are used for the production of untraditional animal feed, as well as many other secondary industries. It is cultivated in about 355,000 fedan, producing about 910,000 ton of sugar annually (Sugar Annual Report of Egypt, USDA-2012). However, the genetic improvement of sucrose yield of these crops turned to be a slow and limited process. Doney, (1988) attributed this to the negative correlation between sucrose concentration and other yield component characters in sugar cane and sugar beet crops. Kholovoda et al., (1985) suggested that the use of in vitro techniques for this purpose (increase sucrose contents) could be of great help. In such materials, it is expected to have no correlation relationship as those existing between separate organs in the whole plant. The present study was carried to induce polyploidy for any possible genetic improvement of sugar cane crop cultivated in Egypt.

\section{MATERIALS AND METHODS}

This work was planned to induce polyploidy in some sugar cane cultivars and evaluation their agronomic characters. So three cultivars were selected and used. This work was conducted at the period that ranged from 2011- 2012.

Attempts for the induction of polyploidy from these three cultivars were undertaken using cuttings with one bud each. About one hundred cuttings from each cultivar were used. Each cutting had two surfaces the first was covered by wax, while the second surface was embedded in solution of colchicine $(0.05 \%)$.

In addition each bud was surrounded by a layer of cotton moistened with the same colchicine solution. After 7 days, cutting were transferred to water and allowed to grow until a shoot system of about $40 \mathrm{~cm}$ was observed. They were then cultivated in the field and allowed to grow under the field conditions. 
Different characteristics were measured. They were:

1- Number of plastids in guard cells of stoma.

2- Size of epidermal cells in leaves.

Point No.1 \& 2 were employed for preliminary screening.

3- Measurement of total soluble solids, plant height and stem diameter.

4- Physico-chemical properties of chromatin and DNA isolated from leaves.

5- Investigation of meiotic chromosomes, when it was possible, and mitotic chromosomes when it was needed.

\section{- Isolation of chromatin:}

The chromatin was isolated according to the method described by Fellenberg and Schömer, (1975) and Seehy et al., (1984).

\section{- Purification of chromatin:}

Chromatin was purified by filtration through Sephadex G-25 Fine using $1 \mathrm{M} \mathrm{NaCl}$ buffer. The purity of chromatin preparations was checked using the criteria of Fellenberg, (1974).

\section{-Thermal Stability and Chemical Composition of Chromatin:}

When purified chromatin showed adequate ultraviolet absorption spectrum, it was then dialyzed three times at $0-2{ }^{\circ} \mathrm{C}$ against the following buffer (1L buffer/10 ml chromatin solution): $0.0014 \mathrm{M} \mathrm{NaCl}$, $0.00025 \mathrm{M}$ Tris $-\mathrm{HCl}, \mathrm{pH}$ 7.2.

\section{- Estimation of melting temperature (Tm-value):}

The UV absorbance for the chromatin at both 260 and $280 \mathrm{~nm}$ was recorded at each one-degree-increase in temperature (the heating rate was $1^{\circ} \mathrm{C} / \mathrm{min}$.). Absorbances at all temperatures were calculated as relative to the absorbance at $50{ }^{\circ} \mathrm{C}$ (Spang and Platt, 1972). The relative absorbance was plotted against the temperature and the Tm-value was calculated as the temperature which gave half the overall increase in relative absorbance.

\section{- Chemical composition of chromatin:}

DNA, total protein, histones and non-histones proteins were determined as $\mu \mathrm{g} / \mathrm{ml}$ chromatin, and then the different proteins were calculated as relative to DNA.

\section{- Isolation of DNA:}

To purified chromatin solution (soluble in $1 \mathrm{M}$ $\mathrm{NaCl}), \mathrm{NaCl}$ was added to a final concentration of 2.5 $\mathrm{M}$, then it was gently shaked, stored at $2^{\circ} \mathrm{C}$ overnight. The DNA was separated from the chromosomal proteins by filtration through Sephadex G-200.
The purity of this DNA was estimated from the UV absorption spectrum at wavelengths in the range of 230$320 \mathrm{~nm}$. The spectrum of DNA contaminated with proteins was distinguished from that of the deproteinized DNA most strikingly by its greater absorption at $230 \mathrm{~nm}$ due to the peptide bonds.

\section{- Estimation of melting temperature of DNA:}

The Tm-value of DNA was calculated in the same way described in estimation of Tm-value of chromatin.

\section{-Estimation of thermal stability and chemical composition:}

In order to estimate the thermal stability of sugar cane chromatin (against temperature) as well as the chemical composition, the following procedure was used:

- Chromatin isolation was done by the method described by Fellenberg and Schömer, (1975), and Seehy et al., (1984).

\section{- Purification of chromatin:}

Chromatin in $1 \mathrm{M} \mathrm{NaCl}$ was purified by chromotography on Sephadex G-25 fine (Pharmcia fine chemicals AB, Uppsala, Sweden). Purified chromatin (soluble in $1 \mathrm{M} \mathrm{Nacl}$ ) was dialyzed against the following buffer: 0.0014 M Nacl + 0.00025 M Tris-Hcl pH 7.2.

\section{- Estimation of Tm-value:}

The procedure was the same as that described by Bonner et al., (1968). From each extraction two estimations were calculated. The absorbance of all investigated samples was recorded every minute at 260 $\mathrm{nm}$ as well as at $280 \mathrm{~nm}$. The relative absorbance was calculated as described by Spang and Platt, (1972) and Seehy et al., (1984). Relative absorbance $=\mathrm{AG} / \mathrm{A} 50^{\circ} \mathrm{C}$, where $\mathrm{AG}$ is the absorbance at a given temperature and A $50{ }^{\circ} \mathrm{C}$, is the absorbance at $50{ }^{\circ} \mathrm{C}$.

\section{- DNA estimation:}

The diphenylamine method of Giles and Myers, (1965) and described by Burton (1968) was used for determination of DNA concentrations. Total protein determined by the method of Lowry et al., (1951). using albumin from bovine serum (Sigma) as standard. Histones were extracted and determined by the method of Lowry et al., (1951). Non-histone proteins were calculated as the differences between the total proteins and histones. Deoxyribonucleic acids, total proteins, histones and non-histones proteins were determined as $\mu \mathrm{g} / \mathrm{ml}$ chromatin and then, the different proteins were calculated as relative to DNA. From the composition of histones and of DNA, one can calculate that if a nucleohistone in which DNA is fully complexed with basic proteins, the mass ratio of histones to DNA should be approximatly 1.35 to 1 (Bonner, 1965). 


\section{RESULTS}

In this work 100 cuttings for each cultivar were used. The results showed that $\mathrm{C} 9$ cultivar was proven to be higher than $\mathrm{PH} 8013$ or NCO 310 in response to polyploid. Using C9 cultivar, $0.09 \%$ cuttings were observed with polyploid cells, while PH 8013 gave 0.04 $\%$ with respect to cultivar NCO 310 no success was observed. Table (1) shows the results observed from this method.

Table 1. Number of cuttings used for the induction of polyploid

\begin{tabular}{lccc}
\hline Cultivar & $\begin{array}{c}\text { No. } \\
\text { cuttings }\end{array}$ & $\begin{array}{c}\text { No. of } \\
\text { polyploid }\end{array}$ & $\%$ \\
\hline C9 & 100 & 9 & 0.09 \\
\hline PH 8013 & 100 & 4 & 0.04 \\
\hline NCO 310 & 100 & 0 & 0 \\
\hline
\end{tabular}

Figures (1, 2, 3 and 4) show the different developmental stages during colchicine treatment and induction of polyploid.

Anatomical study was carried out to compare stomata in different genotypes. It was found that stoma

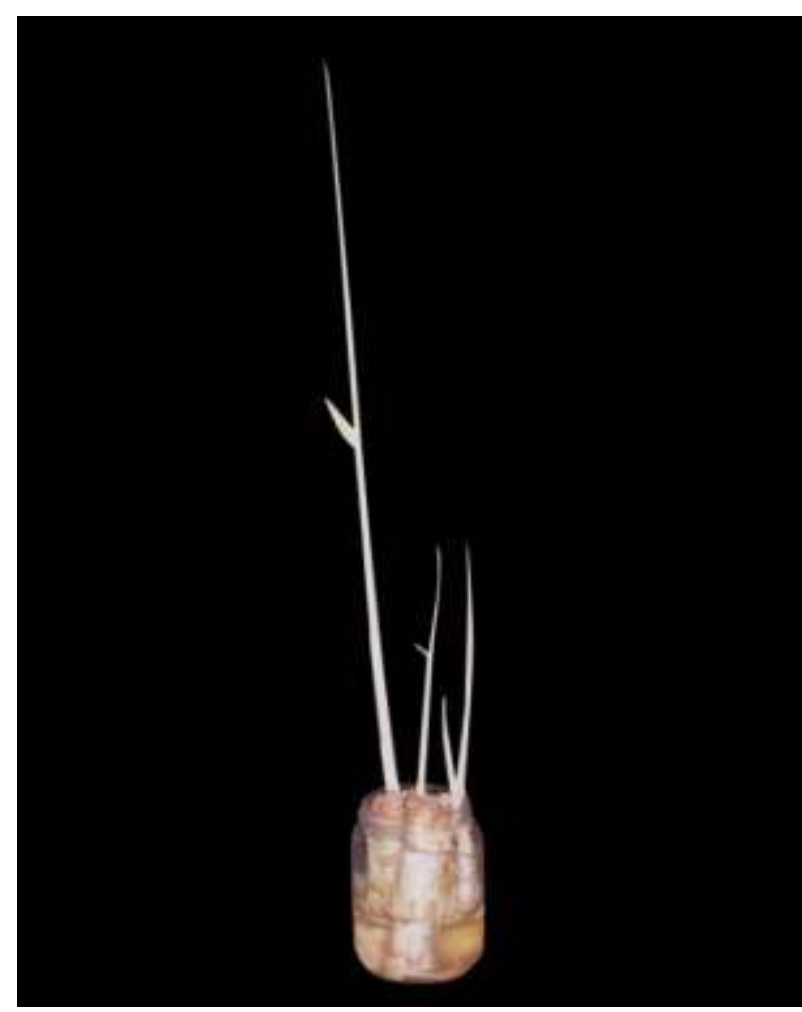

Figure 1. Photograph showing initiation adventitious roots of $\mathrm{C} 9$ cuttings in leaves of polyploid plants was found to be larger than that of diploid plants.

- Plastids in guard cell:

Table (2) shows the number of plastids in guard cell of different genotypes. It ranged from $8-17$ plastids per guard cell.

Table 2. Number of plastids in guard cell of different genotypes of sugar cane

\begin{tabular}{cc}
\hline Cultivar & No. plastids \\
\hline C9 & $8-10$ \\
\hline C9A & $14-17$ \\
\hline
\end{tabular}

\section{- Vascular bundles:}

In this anatomical study size of vascular bundles in different genotype was recorded. Figures $(5 \& 6)$ show that vascular bundle in young leaves of polyploid plants was shown to be larger than that of diploid plants.

\section{- Epidermal cells:}

Anatomical examination of transverse section (T.S.) or young leaves showed that epidermal cells in leaf of polyploid plant were proven to be larger than that of the original cultivar.

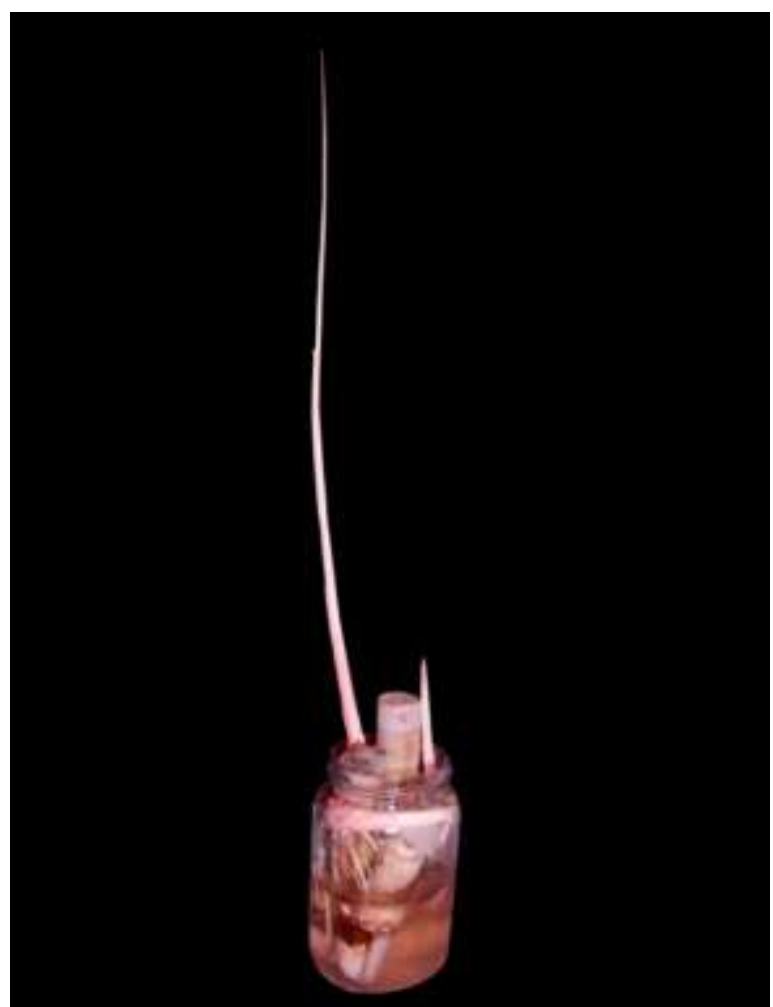

Figure 2. Photograph showing initiation of of adventitious roots of $\mathrm{C} 9$ cuttings 


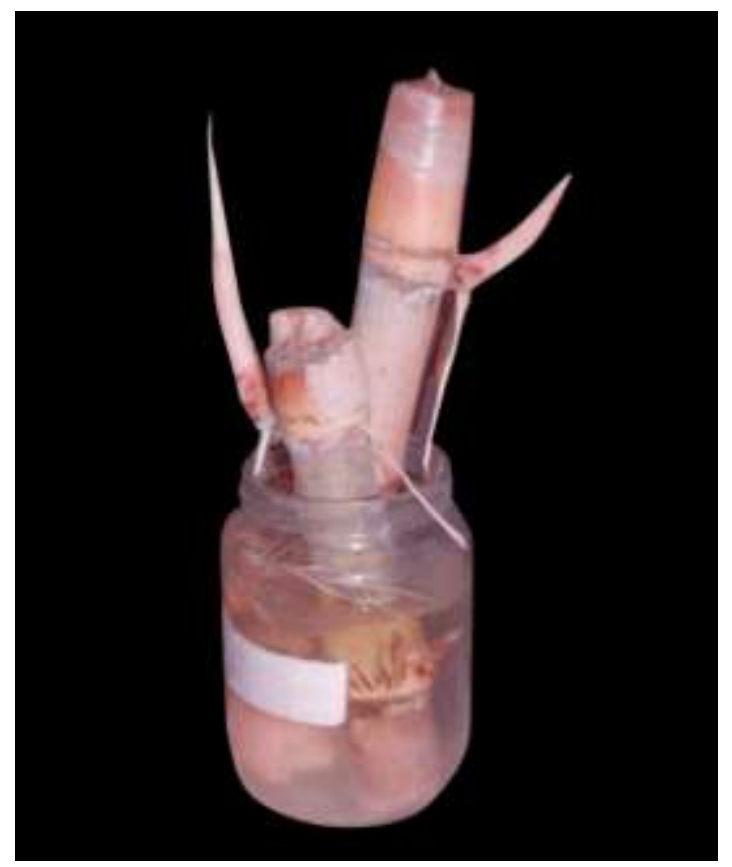

Figure 3. Photograph showing initiation of adventitious roots of $\mathrm{C} 9 \mathrm{~A}$.

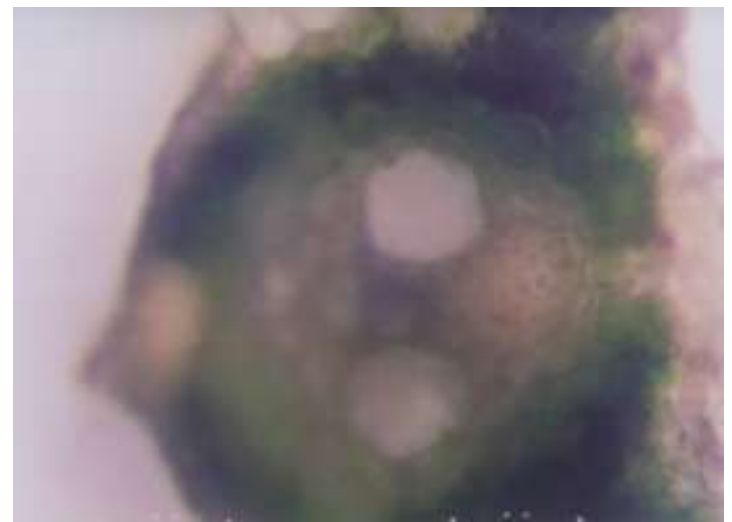

Figure 5. Photomicrograph showing Vascular bundles in a young leaf of cultivar C9

- Chromosome number:

In order to precisely detect the induction of polyploid, buds of cuttings from the observed plants were allowed to germinate under controlled conditions. Adventitious roots were treated with colchicine and chromosome complement was investigated. Chromosome number was found to be 80 chromosomes in diploid cultivar. In polyploid plants a chromosome number of 160 and 240 were observed (Figure $7 \& 8 \&$ 9).

Cytological examination of adventitious root tip cells showed that interphase nucleus of the original cultivar was found to be completely different from that of the polyploidy. Figures (10-13) illustrate these differences where multinuclei were observed.

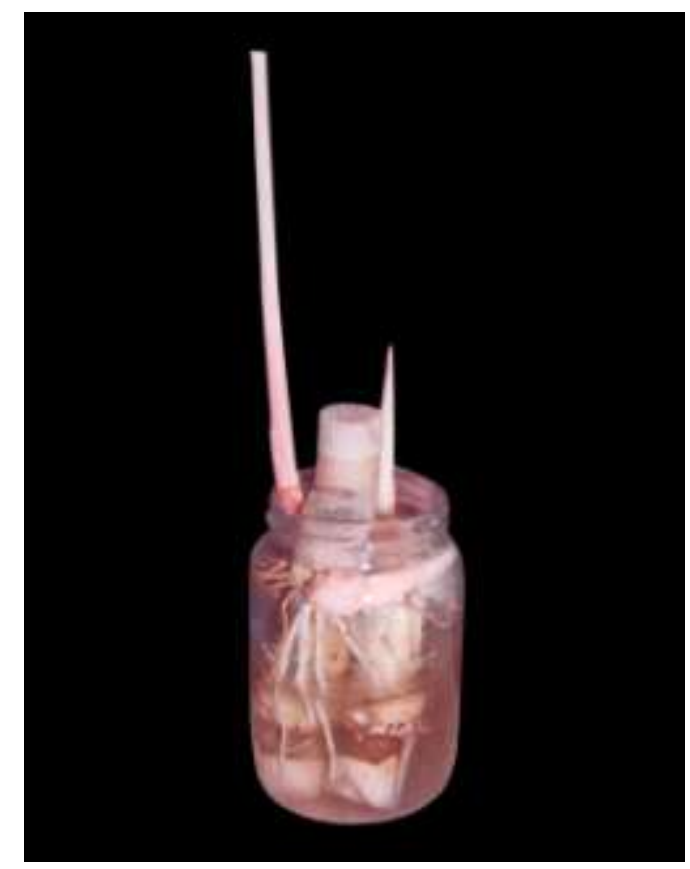

Figure 4. Photograph showing initiation of adventitious roots of $\mathrm{C9A}$

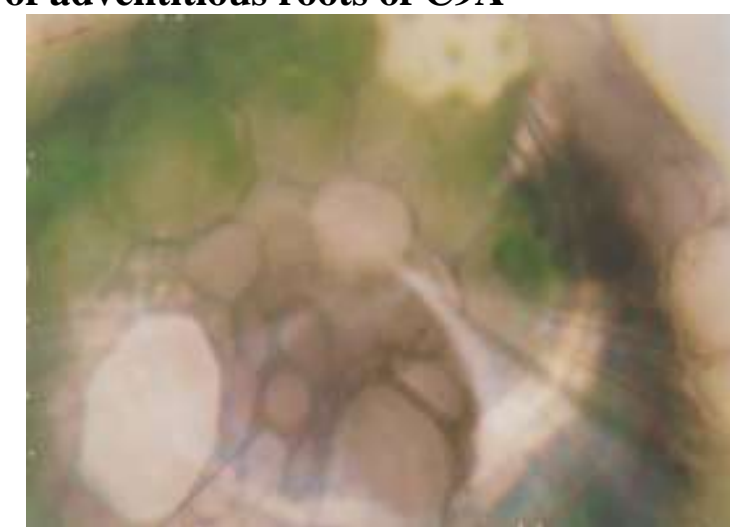

Figure 6. Photomicrograph showing Vascular bundles in a young leaf of genotype C9A

- Physico-chemical properties of chromatin:

In this work chromatin was isolated and purified using Sephadex G-25. Coefficients of absorbance were proven to be highly and fairly sufficient. The ultraviolet absorption spectra as well as coefficients of absorbance are shown in Tables (3, 4 and 5).

\section{- Tm-values for chromatin:}

Temperature of melting for chromatin isolated from leaves of cultivars (C9 \& C9A) at $(260 \mathrm{~nm} \& 280 \mathrm{~nm})$ and melting profiles at $260 \mathrm{~nm}$ as well as to $280 \mathrm{~nm}$ are shown in Figures (14 and 15).

Tm-value was found to be $72.5^{\circ} \mathrm{C}$ for $\mathrm{C} 9$ at $260 \mathrm{~nm}$, while it was $75.5^{\circ} \mathrm{C}$ for $\mathrm{C} 9 \mathrm{~A}$ at $260 \mathrm{~nm}$, Tm-value was found to be $79.5^{\circ} \mathrm{C}$ for $\mathrm{C} 9$ at $280 \mathrm{~nm}$ and $77.5^{\circ} \mathrm{C}$ for C9A at $280 \mathrm{~nm}$. 


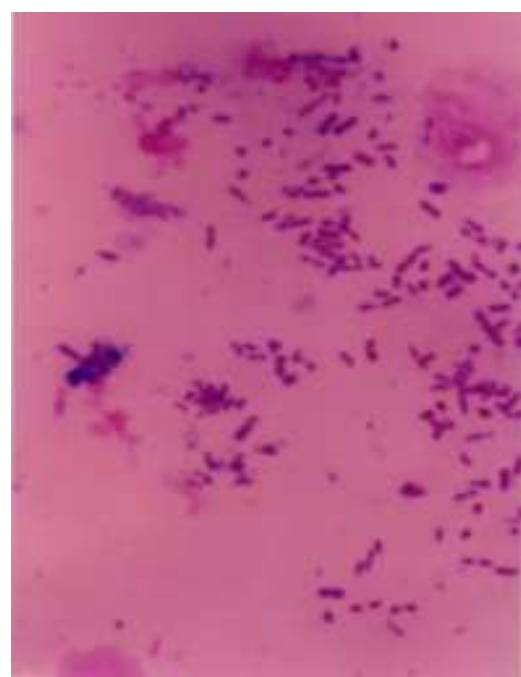

Figure 7. Photomicrograph showing chromosomes of the original cultivar C9 \{80 chromosomes).

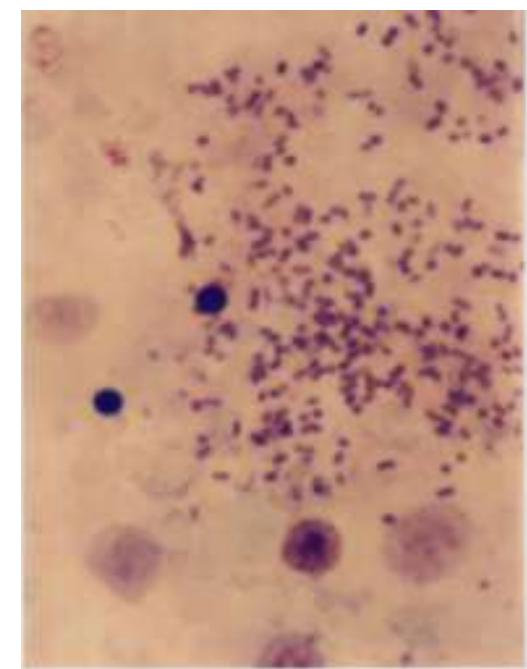

Figure 8. Photomicrograph of sugar cane genotype $\mathrm{C} 9 \mathrm{~A}$ (induced by colchicine) showing chromosomes number of 160 chromosome.

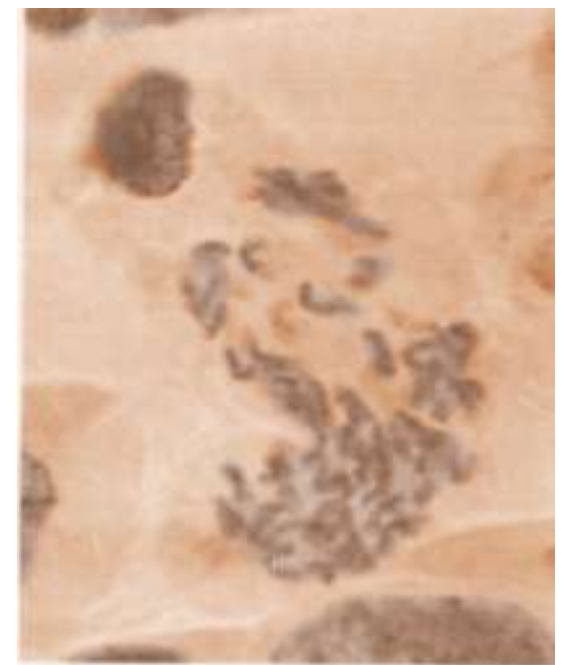

Figure 9. Photomicrograph of sugar cane genotype C9A (induced by colchicine) showing chromosomes number of 240 chromosome.

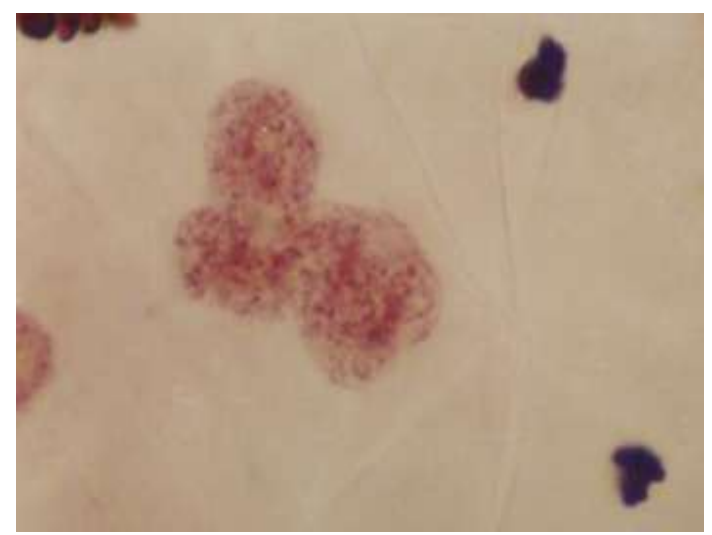

Figures 10. Photomicrograph showing Interphase nucleus of sugar cane cultivar C9

(12)

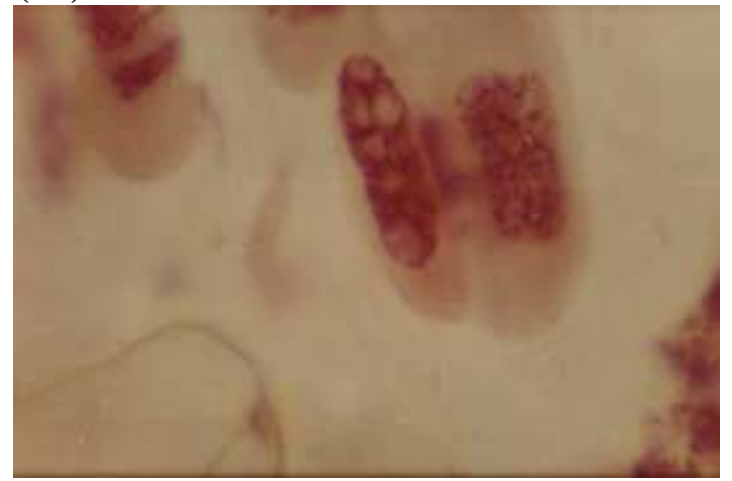

Figures 11, 12. Photomicrograph showing interphase nucleus of sugar cane genotype (C9A).

** Note: that up to 8 nucleolei were observed 
Figures 13. Photomicrograph showing Metaphase stage in adventitious root-tip cells of sugar cane (C9A)

Table 3. Absolute absorbance of purified chromatin isolated from Sugar cane cultivars

\begin{tabular}{ccccccc}
\hline Wavelength nm & $\mathbf{2 3 0}$ & $\mathbf{2 4 0}$ & $\mathbf{2 5 0}$ & $\mathbf{2 6 0}$ & $\mathbf{2 8 0}$ & $\mathbf{3 2 0}$ \\
\hline C9 & 552 & 460 & 660 & 750 & 400 & 62 \\
\hline C9A & 732 & 610 & 882 & 1020 & 540 & 84 \\
\hline
\end{tabular}

Table 4. Coefficients of absorbance for purified chromatin isolated from cultivars C9 and C9A

\begin{tabular}{ccccc}
\hline Variety & $\mathbf{2 6 0 / 2 4 0}$ & $\mathbf{2 5 0 / 2 6 0}$ & $\mathbf{2 8 0 / 2 6 0}$ & $\mathbf{3 2 0 / 2 6 0}$ \\
\hline C 9 & 1.63 & 0.88 & 0.53 & 0.083 \\
\hline C9A & 1.67 & 0.86 & 0.53 & 0.082 \\
\hline
\end{tabular}

Table 5. Temperature of melting of (TM-value) of chromatin isolated from sugar cane cultivars

\begin{tabular}{cccc}
\hline \multirow{2}{*}{ Varieties } & \multicolumn{2}{c}{ Wave length } & \multirow{2}{*}{$\Delta \mathbf{T m}(\mathbf{T m} \mathbf{2 8 0}-\mathbf{T m} \mathbf{2 6 0})$} \\
\cline { 2 - 3 } & 260 & 280 & 7 \\
\hline C9 & 72.5 & 79.5 & 2 \\
\hline C9A & 75.5 & 77.5 & \\
\hline
\end{tabular}

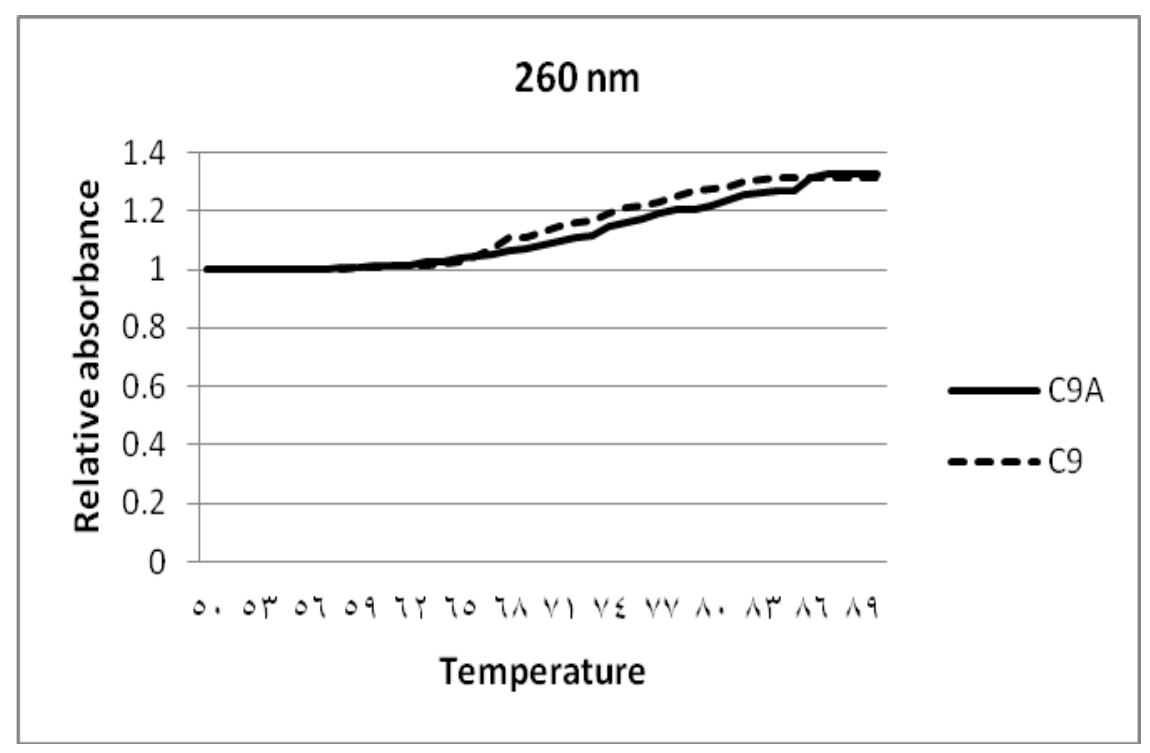

Figure 14. Melting profile of chromatin isolated from sugar cane (Cultivars C9 and C9A) at $260 \mathrm{~nm}$. Melting was carried out in diluted saline solution $0.0014 \mathrm{M} \mathrm{NaCl}$ 


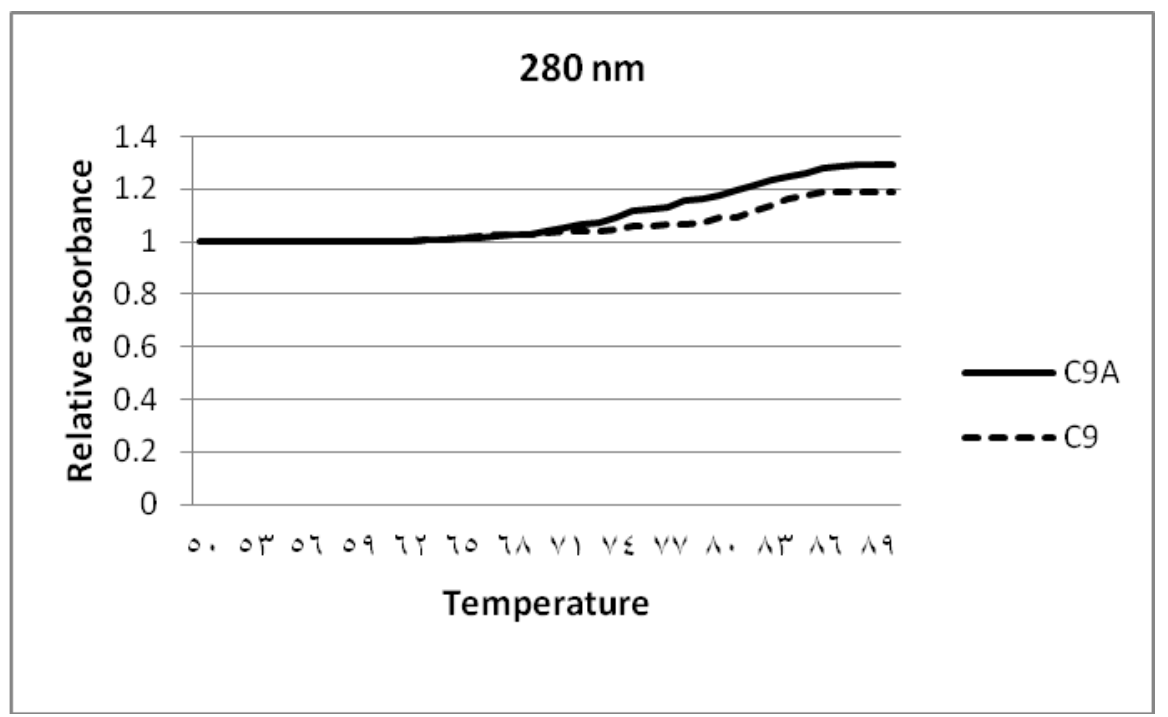

Figure 15. Melting profile of chromatin isolated from sugar cane (Cultivars C9 and C9A) at $280 \mathrm{~nm}$. Melting was carried out in diluted saline solution $0.0014 \mathrm{M} \mathrm{NaCl}$.

- Tm-values for DNA:

Melting profiles at $260 \mathrm{~nm}$ as well as $280 \mathrm{~nm}$ are shown in Figures (16 and 17). The obtained results indicated that $\mathrm{Tm}$ value for deproteinized DNA of $\mathrm{C} 9$ was not the same as that for C9A; this difference was found to be significant. It seems probable that this difference was caused by DNA-under-replication, and this would be discussed later.

An attempt was carried out to estimate the fraction of genome which melts at $65^{\circ} \mathrm{C}$ and $70{ }^{\circ} \mathrm{C}$ (Table 6) these results reflect differential structure of chromatin isolated from $\mathrm{C} 9$ compared with that of C9A.

Table $(7,8)$ show the chemical compositions of chromatin isolated from young leaves of C9 and C9A. Comparing the results shown in these tables one can conclude that C9A was proven to be higher in its transcriptional activity compared with C9 (Total acidic protein percent of total was $55.30 \%$ versus $45.67 \%$.

Table (9) Repressed and active fraction of genome. The data clearly show that $\mathrm{C} 9 \mathrm{~A}$ had active fraction of genome $(31.85 \%)$ Vs $(20 \%)$ for C9.

Table (10) Hyperchromicity obtained after melting of $\mathrm{C} 9$ chromatin. It was similar to that obtained for C9A, giving an evidence that the base composition is approximately similar.
An attempt was carried out to isolate DNA for chromatin. Table (11) and Figure (18) show the UV absorption spectra of DNA isolated from C9 and C9A cultivars leaves.

Coefficients of absorbance for purified chromatin isolated from cultivars $\mathrm{C} 9$ and $\mathrm{C} 9 \mathrm{~A}$ are given in Table (12).

Fractions of DNA which melts at $65^{\circ} \mathrm{C}$ and $70^{\circ} \mathrm{C}$ are given in Table (13). At $280 \mathrm{~nm}$ values was proven to be similar where at $260 \mathrm{~nm}$ significant differences were obtained, giving an evidence that the DNA underreplication is achieved at A-T rich regions.

Temperature of melting for deproteinized DNA (Table 14) show that Tm-value was 73 and $70^{\circ} \mathrm{C}$ at 260 $\mathrm{nm}$ for $\mathrm{C} 9$ and $\mathrm{C} 9 \mathrm{~A}$, respectively. It was proven to be 76 and $74^{\circ} \mathrm{C}$ for C9 and C9A, respectively. Such differences in Tm-value for deproteinized DNA would be caused by DNA-under-replication phenomenon.

Agronomic characters an attempt was carried out to estimate some agronomic traits. Total soluble solids, plant height and stem diameter were estimated in both genotypes ( $\mathrm{C} 9$ and $\mathrm{C} 9 \mathrm{~A})$. Table (15) illustrates the average of these characters.

Table 6. Fraction of Genome which melts at $65^{\circ} \mathrm{C}$ and $70{ }^{\circ} \mathrm{C}$

\begin{tabular}{ccccc}
\hline \multirow{2}{*}{$\begin{array}{c}\text { Source of } \\
\text { chromatin }\end{array}$} & \multicolumn{2}{c}{$\begin{array}{c}\text { Fraction which melts } \\
\text { at 65 }{ }^{\mathbf{}} \mathbf{C}\end{array}$} & \multicolumn{2}{c}{$\begin{array}{c}\text { Fraction which melts } \\
\text { at 70 }\end{array}{ }^{\mathbf{0}} \mathbf{C}$} \\
\cline { 2 - 5 } & $\mathbf{2 6 0} \mathbf{~ n m}$ & $\mathbf{2 8 0} \mathbf{~ n m}$ & $\mathbf{2 6 0} \mathbf{~ n m}$ & $\mathbf{2 8 0} \mathbf{~ n m}$ \\
\hline C9 & $11.96 \%$ & $3.46 \%$ & $25.76 \%$ & $14.18 \%$ \\
\hline C9A & $8.95 \%$ & $4.18 \%$ & $41.21 \%$ & $10.80 \%$ \\
\hline
\end{tabular}


Table 7. Chemical composition of purified chromatin isolated from leaves of Sugar cane

\begin{tabular}{cccccc} 
Cultivar & DNA & $\begin{array}{c}\text { Total proteins } \\
(\mathbf{T})\end{array}$ & $\begin{array}{c}\text { Histone } \\
(\mathbf{H})\end{array}$ & $\begin{array}{c}\text { Acidic proteins } \\
(\mathbf{A P})\end{array}$ & $\begin{array}{c}\text { Acidic proteins; \% } \\
\text { of Total } \\
\text { AP }\end{array}$ \\
\hline C9 & 118 & 236 & 128 & 108 & $45.67 \%$ \\
\hline C9A & 215 & 443 & 198 & 245 & $55.30 \%$ \\
\hline
\end{tabular}

$*_{\mu \mathrm{g}} / \mathrm{ml}$ chromatin soluble in $1 \mathrm{~m} \mathrm{Nacl}$.

Table 8. Chemical composition of purified chromatin isolated from leaves of Sugar cane

\begin{tabular}{cccccc}
\hline Cultivar & DNA & $\begin{array}{c}\text { Total proteins } \\
(\mathbf{T})\end{array}$ & $\begin{array}{c}\text { Histones } \\
(\mathbf{H})\end{array}$ & $\begin{array}{c}\text { Acidic proteins } \\
(\mathbf{A P})\end{array}$ & $\begin{array}{c}\text { Acidic proteins \% } \\
\text { of Total } \\
\text { AP \% }\end{array}$ \\
\hline C9 & 1 & 2 & 1.08 & 0.92 & - \\
\hline C9A & 1 & 2.06 & 0.92 & 1.14 & - \\
\hline
\end{tabular}

* Relative to its DNA.

Table 9. Repressed and active fraction of genome

\begin{tabular}{lcc}
\hline Cultivar & $\begin{array}{c}\text { RFG } \\
\text { Repressed fraction of genome }\end{array}$ & $\begin{array}{c}\text { AFG } \\
\text { Active fraction of genome }\end{array}$ \\
\hline C9 & $1.08 / 1.35 * 100=80$ & $100-80=20 \%$ \\
\hline C9A & $0.92 / 1.35 * 100=68.14$ & $100-68.14=31.85 \%$ \\
\hline
\end{tabular}

Table 10. Hyperchromicity of purified chromatin isolated from sugar cane leaves

\begin{tabular}{lcc}
\hline Source & \multicolumn{3}{c}{ Wavelength } \\
\cline { 2 - 3 } & $\mathbf{2 6 0} \mathbf{~ n m}$ & $\mathbf{2 8 0} \mathbf{~ m m}$ \\
\hline C9A & $31.3 \%$ & $28.7 \%$ \\
\hline C $~$ & $32.6 \%$ & $28.9 \%$ \\
\hline
\end{tabular}

Table 11. Ultraviolet absorption spectra of DNA isolated from sugar cane leaves

\begin{tabular}{ccccccccc}
\hline Cultivar & $\mathbf{2 3 0}$ & $\mathbf{2 4 0}$ & $\mathbf{2 5 0}$ & $\mathbf{2 6 0}$ & $\mathbf{2 7 0}$ & $\mathbf{2 8 0}$ & $\mathbf{2 9 0}$ & $\mathbf{3 2 0}$ \\
\hline C 9 & 0.477 & 0.620 & 0.902 & 1.115 & 1.00 & 0.600 & 0.300 & 0.01 \\
\hline C9A & 0.582 & 0.632 & 0.922 & 1.090 & 0.922 & 0.610 & 0.290 & 0.01 \\
\hline
\end{tabular}

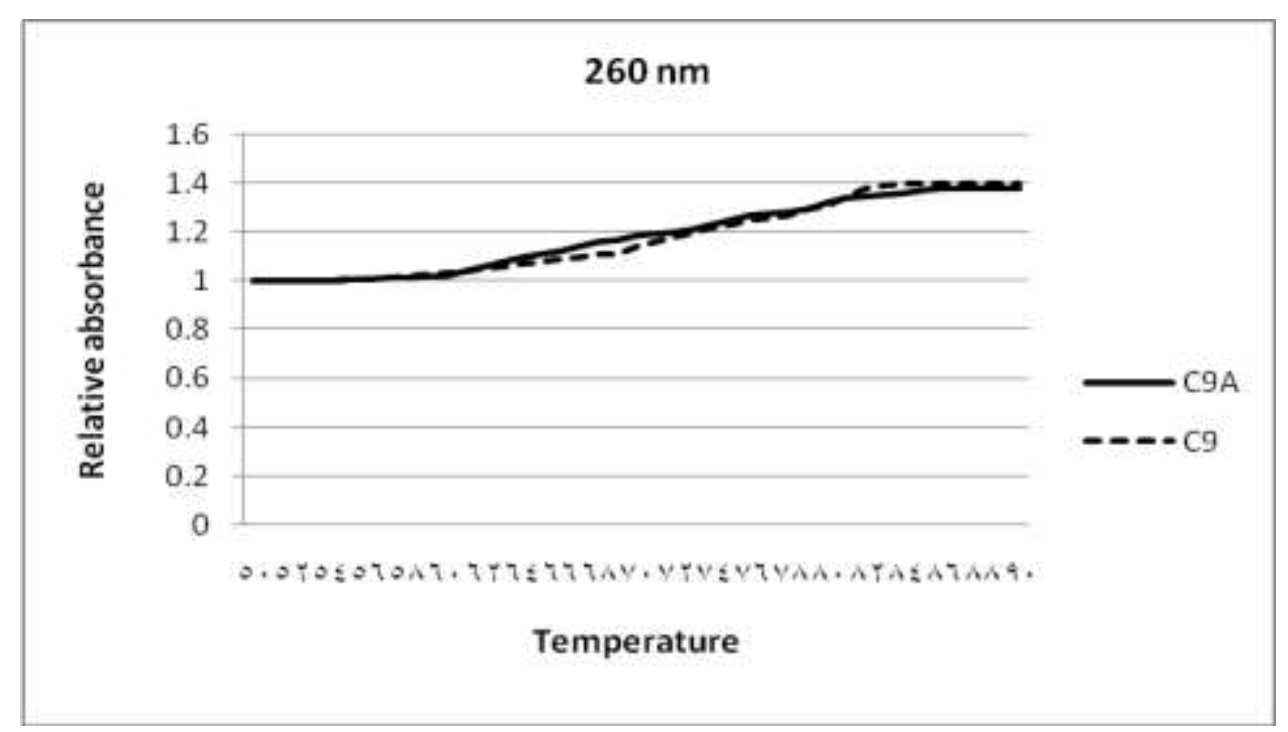

Figure 16. Melting profile of DNA isolated from sugar cane (Cultivars C9 and C9A) at 260 $\mathrm{nm}$. Melting was carried out in diluted saline solution $0.0014 \mathrm{M} \mathrm{NaCl}$ 


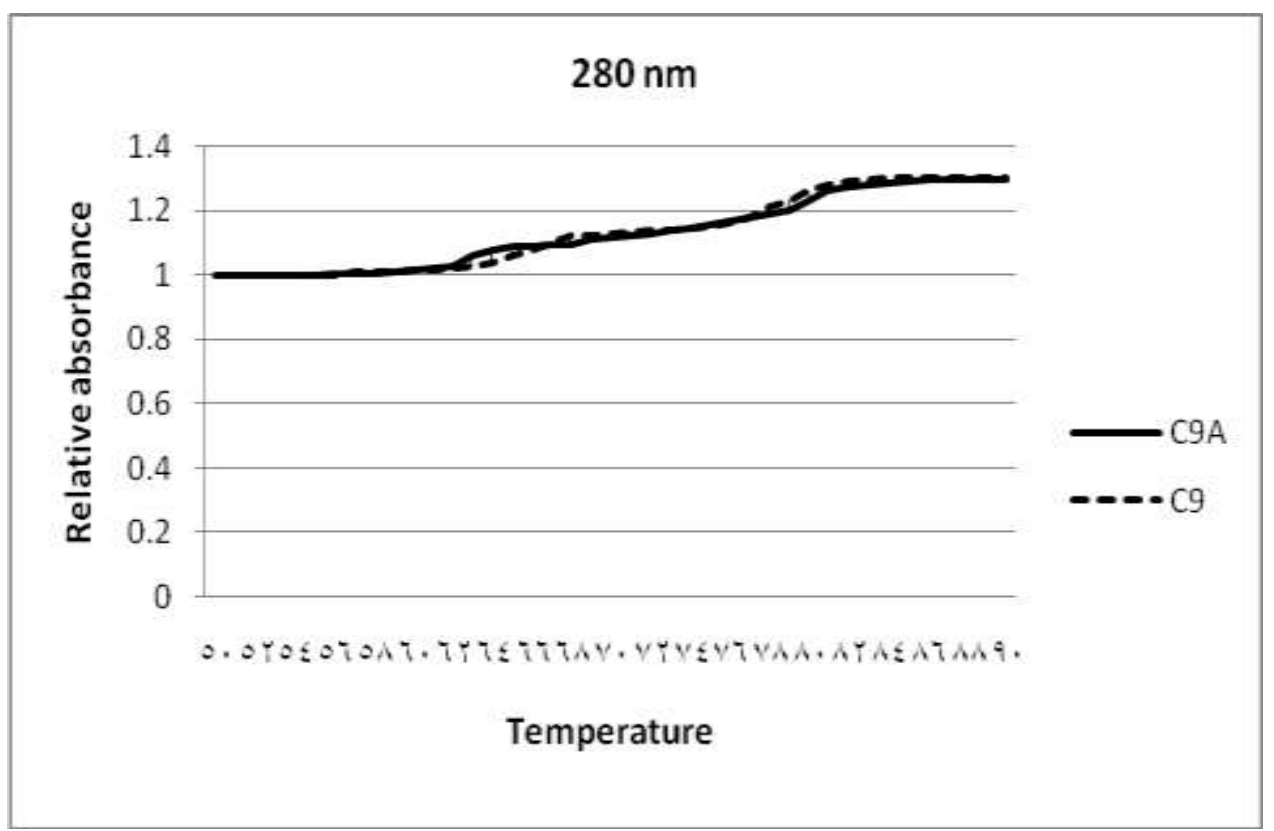

Figure 17. Melting profile of DNA isolated from sugar cane (Cultivars C9 and C9A) at 280 nm. Melting was carried out in diluted saline solution $0.0014 \mathrm{M} \mathrm{NaCl}$.

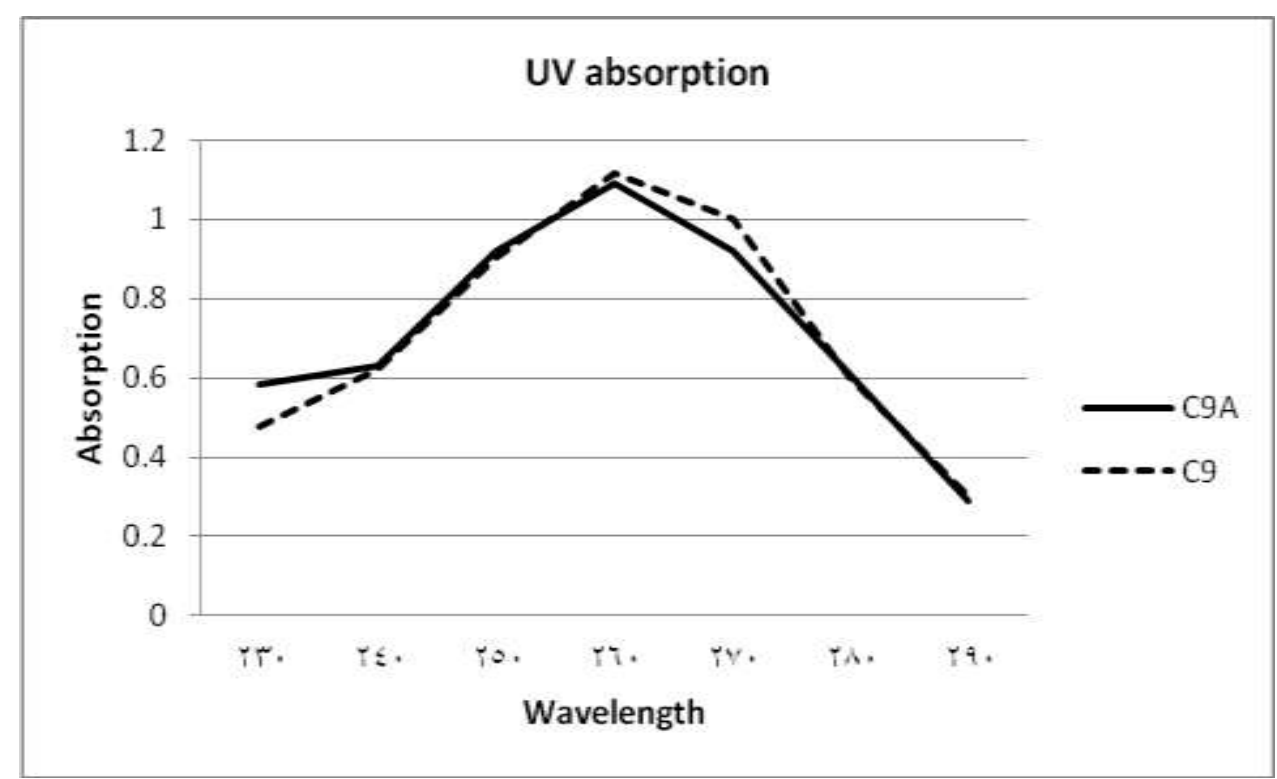

Figure 18. Ultraviolet absorption spectrum of DNA isolated from sugar cane leaves cultivars C9 and C9A.

Table 12. Coefficients of absorbance for purified chromatin isolated from cultivars $\mathrm{C} 9$ and C9A

\begin{tabular}{ccccc}
\hline Variety & $\mathbf{2 6 0 / 2 4 0}$ & $\mathbf{2 5 0 / 2 6 0}$ & $\mathbf{2 8 0 / 2 6 0}$ & $\mathbf{3 2 0 / 2 6 0}$ \\
\hline C9 & 1.79 & 0.81 & 0.54 & 0.019 \\
\hline C9A & 1.72 & 0.84 & 0.55 & 0.012 \\
\hline
\end{tabular}


Table13. Fraction of DNA which melts at $65^{\circ} \mathrm{C}$ and $70{ }^{\circ} \mathrm{C}, \%$

\begin{tabular}{cccccc}
\hline \multirow{2}{*}{ Cultivar } & \multicolumn{2}{c}{$\mathbf{2 6 0} \mathbf{~ n m}$} & $\mathbf{6 5}$ & $\mathbf{2 8 0} \mathbf{~ n m}$ \\
\cline { 2 - 6 } & $\mathbf{6 5}$ & $\mathbf{7 0}$ & 6 & $\mathbf{7 0}$ \\
\hline C9 & 8 & 14 & 8 & 11.5 \\
\hline C9A & 11 & 19 & 11.5 \\
\hline
\end{tabular}

Table 14. Temperature of melting (Tm-value) of DNA isolated from cane leaves

\begin{tabular}{ccc}
\hline Cultivar & $\mathbf{2 6 0} \mathbf{~ n m}$ & $\mathbf{2 8 0} \mathbf{~ n m}$ \\
\hline C9 & 73 & 76 \\
\hline C9A & 70 & 74 \\
\hline
\end{tabular}

Table 15. average of some agronomic characters estimates in this work

\begin{tabular}{|c|c|c|c|}
\hline Genotypes & T.S.S & Plant height & Stem diameter \\
\hline C9 & $21.6 \%$ & $2.01 \mathrm{~m}$ & $2.11 \mathrm{~cm}$ \\
\hline C9A & $21.81 \%$ & $2.41 \mathrm{~m}$ & $2.82 \mathrm{~cm}$ \\
\hline
\end{tabular}

A key goal of sugarcane breeding programs is to increase sugar yield by increasing sugar production per area, which is closely associated with height, diameter and number of the stalk, along with sugar accumulation in the stalk. Sugar yields have been generally improved by increasing total biomass rather than directly increasing sugar concentration in stalks (Jackson, 2005). Regarding sugar accumulation in the cane, stalk diameter seems more important than length (Milligan et al., 1990). Other important traits to be considered are vigor and productivity of the ratoon (Aitken et al., 2008). Future varieties bred specifically for secondgeneration biofuels will be dissociated from highsucrose yields, but instead will aim at total biomass production per area.Some traits are additive while others present dominant effects. Additive effects can be useful for breeding in early generations of the program while dominant effects are more useful in hybrids (Liu et al., 2007). Increase of sugar yield has always been a major goal of breeding programs.

Most functional genomics projects performed in the 1990's focused on sucrose content, disease resistance and stress tolerance, and involved several techniques, such as EST characterization, microarray and SAGE analyses (Vettore et al., 2003; Papini-Terzi et al., 2005; Calsa Jr \& Figueira 2007; Menossi et al., 2008; PapiniTerzi et al., 2009; Waclawovsky et al., 2010; Iskandar et al., 2011). The post-genomic era comprises the use of this information into breeding programs, with the identified markers that reveal expression profile of genes in different environmental conditions (Moore, 2005; Waclawovsky et al., 2010; Khan et al., 2011).

However, sugarcane is a polyaneuploid species, and statistical segregation models have been developed to fit diploid organisms interpretations (Parida et al., 2010; Tabasum et al., 2010; Swapna et al., 2010). About 5\% of publicly available sugarcane unigenes present single sequence repeats, and the frequency of perfect microsatellites is one marker for every $10.4 \mathrm{~kb}$ (Parida et al., 2010). Considering this, many polymorphic loci obtained during crossings cannot be properly analyzed, given the difficulties due to polyploid segregation (Garcia et al., 2006). In breeding of diploid species, molecular markers are significant for MAS through the use of single nucleotide polymorphisms (SNPs) for polygenic traits such as yield components and disease resistance. The polyploidy constitution of sugarcane makes it as the most difficult crop to apply MAS, that is a sugarcane breeders's dream. Finally, although many available papers report the identification of markers associated with qualitative and quantitative traits in sugarcane, it is noteworthy to mention that they have had very little impact in sugarcane breeding up to now.

The present study was carried out to induce polyploidy in sugar cane crop cultivated in Egypt. To achieve such a purpose the following was undertaken:

1. Three cultivars of sugar cane grown at Sabbahia Agricultural Research Station were chosen for their economical importance and were cultivated under conditions that stimulate flowering processes, Meiotic chromosomes of these cultivars were examined.

2. Attempts were conducted to induce polyploidy as described in the Materials and Methods part.

3. Selection for ploidy was carried out employing the different criteria.

4. A comparison between physico-chemical properties of chromatin isolated from nuclei as well as of DNA was done to investigate the transcriptional activity. 
5. Some agronomic traits were measured (Total soluble solids, plant height and stem diameter)

6. Chromosome complements in mitosis of adventitious roots were obtained when needed.

Sugar cane, as a perennial grass plant, belongs to the saccharum officinarum species as a member of saccharum genus. Sugar cane (Saccharum) is a species of between 6-37 species (depending on taxonomic interpretation) of tall grasses (family poaceae, tribe Andropogoneae), native to warm temperate to tropical regions of the old world. They have stout, jointed fibrous stalks 2-6 m tall and sap rich in sugar. However, very little is known about sugar cane genetics. The basic chromosome number estimation in saccharum have been as diverse as $\mathrm{x}=5,6,8,10$ or 12 and varied with species (Sreenivasan et al., 1987). The mating systems in natural populations have not been documented. Despite these drawbacks, sugar cane is an example of very successful use of alien genetic resources. The interspecific hybridization programs that were carried out at the beginning of the century in java in India revolutionized sugar cane breeding. Modern sugar cane varieties result from interspecific hybridization and may contain more that 100 chromosomes contributed by up to five different species (Heinz 1987). It encompasses very diverse euploid and aneuoploid members $(2 \mathrm{n}=40-$ 128), Lu et al, (1994). This wide range of chromosome number of sugar cane gives the breeders the chance to successfully practice his selection program.

Today's commercial sugar cane cultivars are almost exclusively back cross derivatives involving $S$. officinarum and $S$. spontaneum. However, only a few clones of these species were used this narrow genetic bass of modern hybrid varieties is surely one of the principal causes of the present slow rate of sugar cane breeding process (Berding and Roach, 1987).

In Egypt, sugar cane provides about $55 \%$ of the sugar supply, while sugar beet provides $45 \%$. There is gab of about 850.000 tons of sugar between the consumption and the production of sugar and this amount is yearly imported from abroad and costs the country a lot of foreign currency. The plan of the government is to minimize this gab by the extension of both crops cane and beet. In sugar cane only vertical extension could be applied because horizontal extension needs a lot of irrigation water which is limited. To develop new desired sugar cane varieties and to improve the existing ones is the main goal of the breeder to achieve the vertical extension in sugar cane.

Many of the desirable characters are quantitative so multivariate statistical techniques have been suggested and utilized to a limited extent to measure genetic and phenotypic divergence among entries and genotypes to aid in planning crosses among genotypes belonging to different clusters (Whitehouse, 1969; Goodman, 1973; Sneath, 1976; Camussi et al., 1983; Kwon-Ndung and Imolehin, 2007; Amer Rasul et al., 2010; Creste et al., 2010; Swapna Simon \& Hemaprabha, 2010; Wang et al. (2010) and Sanjay Kumar \& Devendra Kumar, 2012). Characterization and quantification of genetic diversity, both within and between populations, has long been a major goal in evolutionary biology. In plant breeding programs, information concerning the genetic diversity within a crop species is essential for rational use of genetic resources, it is particularly useful in the characterization of individual accessions and cultivars, in detecting duplications of genetic material in collections, and as a general guide in the choice of parents for breeding hybrids.

Routine methodologies were described for epicuticular wax. Stomata characters and opening (Rai, 1999): stomata characters and opening: leaf water content (Karakas et al., 1997): Pyruvate orthophosphate kinase activity (Du et al., 1998); regulation of C4 photosynthesis and sugar accumulation (Nose et al., 1994; Madan et al., 1988); chlorophyll content (Li and Zhou, 1991; Ortega et al., 1984., Jagtap et al., 1992) and proline content in sugarcane leaves (Jagtap et al., 1992).

Stomata characters were measured following nail paints peeling technique as described by (Capellades $e t$ al., 1990), by applying cellulose acetate (clear nail polish), to the upper leaf surface, which was peeled and examined microscopically for length $(\mu)$. Width $(\mu)$ and number per mm square (no $\mathrm{mm}-2$ ) of stomata.

Leaf relative water content (RWC) was determined by excising $100 \mathrm{~mm}^{2}$ of leaf. Weighed and then reweighted after floated on distilled water for 24 hours. Oven drying at $80{ }^{\circ} \mathrm{C}$ to get the dry weight. RCC = (FW-DW) / (TW-DW) where FW= leaf fresh weight. $\mathrm{DW}=$ dry weight and $\mathrm{TW}=$ tugid weight (Mu-Qing and Ru-Kai, 1998). Soil moisture content was determined as described by Anderson and Ingram (1993), on dry weight basis. Three samples each of $50 \mathrm{~g}$. weighing, then dried at a constant weight at $105{ }^{\circ} \mathrm{C}$. The dry weight was recorded and the moisture content by ((sample wet weight - Oven dry weight) / Oven weight) $\mathrm{x} 100$.

Drought tolerance capacity .(DTC) were determined following Na-EDTA method developed by Dwivedi et al., (1998), by extracting one gram air dry leaf in $20 \mathrm{ml}$ $0.025 \mathrm{M} \mathrm{Na} 2$ EDTA and boiling it for 25-30 minutes in a water bath. After cooling, $\mathrm{pH}$ was measured. The percent fall in $\mathrm{pH}$ as compared to the control was recorded as DTC. Quantitatively, fall of $\mathrm{pH}>3 \%$ 
indicates as drought tolerant genotype and fall of $\mathrm{pH}<$ $1.7 \%$ as sensitive genotypes.

Chromosome number:

In order to precisely detect the induction of polyploid, buds of cuttings from the observed plants were allowed to germinate under controlled conditions. Adventitious roots were treated with colchicine and chromosome complement was investigated. Chromosome number was found to be 80 chromosomes in diploid cultivar. In polyploid plants a chromosome number of 160 and 240 were observed.

Cytological examination of adventitious root tip cells showed that interphase nucleus of the original cultivar was found to be completely different from that of the polyploidy. Multinuclei were observed; giving an evidence that nucleolar organizing region is repeated.

Water stress treatment significantly reduced stomata length $(\mathrm{p}=0.00)$, width $(\mathrm{p}=0.00)$ and increases the number per unit area $(\mathrm{p}=0.00)$. Stomata length and width decrease higher in L6 and 26 compare to L10, 22 and L14. The number of stomata per $\mathrm{mm} 2$ was less in drought tolerant varieties compare to sensitive ones. Stomata characters play an important role in transpiration of water and gas exchange. The size and number of stomata determined the ability of the plant to lose or retain moisture. The bigger the size, the greater the amount of water is expected to be transpired from the leaves. Plate 1 shows an impression of microphotograph on nail polish impression of stomata form the upper surface of tested plants.

Cytological examination revealed that diploid, triploid, tetraploid plants were observed, giving precise evidence that inducing of polyploidy was achieved. However, evaluation of agronomic traits or characters needs propagation for the obtained plants, and this would be done. However, this step is now being carried out at Sabbahia station for sugar crops.

Anatomical observations showed that stomata size, number of plastids in guard cells, size of vascular bundles in young leaves, and size or volume of epidermal cells (of leaves) are considered an adequate tool for characterization of ploidy.

Analysis of total soluble solids (T.S.S), stem diameter; and stem lenghth showed that there are differences between $\mathrm{C} 9$ cultivar and C9A Cites product from the induction of polyploidy.

With respect to the physico-chemical properties temperature of melting was proven to be at $260 \mathrm{~nm}$ lower than that at $280 \mathrm{~nm}$, giving an evidence that DNA was shown to be in its primary structure. At $260 \mathrm{~nm}$ chromatin of the original cultivar was shown to be less active compared with that of its product by the induction of polyploidy (C9A). The active fraction was shown to be $20 \%$ and $31.85 \%$, respectively. This result may reflect the higher transcriptional activity detected in C9A chromatin.

Regarding the physico-chemical properties of deproteinized DNA the results showed that melting profiles as well as temperature of melting of DNA isolated from C9 was shown to be different from that of C9A. This result may reflect that DNA-under-replication was performed. However, one can assume that this DNA-under-replication was shown to be in $\mathrm{A}=\mathrm{T}$ rich region. In conclusion, these measurements might be useful in evaluative purposes and breeding program.

\section{REFERENCES}

Aitken, K.S.; Hermann, S.; Karno, K.; Bonnett, G.D.; McIntyre, L.C. \& Jackson, P.A. (2008). Genetic Control of Yield Related Stalk Traits in Sugarcane, Theoretical and Applied Genetics, Vol.117, No.7, (November 2008), pp. 1191-1203, ISSN 0040-5752.

Amer Rasul, Mansoor-ul-Hassan, Anjum Suhail and Shahbaz Talib Sahi (2010). The Impact of Some Physiomorphic Characters of Sugarcane Genotypes on Their Resistance Against Sugarcane Pyrilla, Pyrilla perpusilla WIK. (Lophopidae: Homoptera). Pak. J. Agri. Sci., Vol. 47(4), 339-344.

Anderson, J. M. and Ingram, J. S. I. (1993). Tropical soil biology. A handbook of methods, $C A B$ International. Wallingford, UK 93-112.

Berding, N. and B. T. Roach, (1987). Germplasm collection, maintenance and use. In. D-J. Heinz (Ed.) sugar cane improvement through breeding. Elsevier press, Amesterdam, pp 143-210.

Bonner, J. (1965). The molecular biology of development. Oxford University press. Oxford. Pp 155.

Bonner, J., M. E. Dahmus, D. Fambrough, R. C. Huang, K. Marushige, and D. Y. H. Tuan (1968). The biology of isolated chromatin, Sci., 159: 47-56.

Bourgin, J.P (1983). Protoplasts and the isolation of plant mutants. In "protoplasts', (Potrykus et al., Eds), P. 43, Birkhauser. Basel.

Burton, K. (1968). Determination of DNA concentration with diphenylamine. In methods in enzymol., vol. XIIB, p.163. Newyork: Academic press.

Calsa Jr., T. and Figueira, A. (2007). Serial Analysis of Gene Expression in Sugarcane (Saccharum spp.) Leaves Revealed Alternative C4 Metabolism and Putative Antisense Transcripts. Plant Molecular Biology, Vol.63, No.6, pp. 745-762, ISSN 0735-9640.

Camussi, A.; P. L. Spagnoletti Zeuli, and P. Melchiorre (1983). Numerical taxonomy of latin maize populations: Genetic distances on the basis of heterotic effects. Maydica 28: 411-424. 
Capellades, M., R. Fountarnau., C. Carulla., and P. Debergh (1990). Environmental influences anatomy of stomata and epidermal cells in tissue-cultured Rosa multiflora Hournal Amer. Soc. Hort. Sci. 115 (1):141-145.

Creste, S.; Pinto, L.R.; Xavier, M.A. \& Landell, M.G.A. (2010). Sugarcane Breeding Method and Genetic Mapping, In: Sugar Cane Bioethanol: $R \& D$ for productivity and sustainability, L.A.B. Cortez (Ed.), 353357, Blucher, ISBN: 9788521205302 , Sao Paulo.

Doney, D. L. (1988). Selection for sucrose yield in stressed sugar beet seedlings. Crop Scince, 28 (2): 245-247.

Du, Y.C., Nose, Wasano, K. and Uchida, Y. (1998). Response to water stress of enzymes activites and metabolic levels in relation to sucrose and starch synthesis, the Calvin cycle and the C4 pathway in sugarcane (Saccharum sp.) leaves. Aust, Journal of plant physiology 25:253-260.

Dwivedi, R. S., Srivastava, K. K., Solomon. S. and Singh, K. (1998). Rapid test for drought resistance in Sugarcane. Sugar Cane, Spring Supplement, 31-32.

Fellenberg, G (1974). chromosomal protein. Stuttgart ulmer.

Fellenberg, G., and Schömer, U (1975). Direct effect of IAA upon isolated chromatin of ethiolated pea saeedlings. Z. Pflanzenphysiol. 75 (5), 444-456.

Garcia, A.A.; Kido, E.A.; Meza, A.N.; Souza, H.M.; Pinto, L.R.; Pastina, M.M.; Leite, C.S.; Silva, J.A.; Ulian, E.C.; Figueira, A. \& Souza, A.P. (2006). Development of an Integrated Genetic Map of a Sugarcane (Saccharum spp.) Commercial Cross, Based on a Maximum-Likelihood Approach for Estimation of Linkage and Linkage Phases. Theorical and Applied Genetics, Vol.112, No.2, (January 2006), pp. 298-314, ISSN 0040-5752.

Giles, K. W., and A. Myers (1965). A improved Diphenyleamine method for the estimation of deoxyribonucleic acid, Nature, 206:93.

Goodman, M. M. (1973). Genetic distances: Measuring dissimilarity among populations. Yearb. Phys. Anthropol 17: $1-38$

Heinz D. J. (1987). Sugar cane improvement; current productivity and future opportunities, In: copersucar Breed Worksh. Copersucar, Sao Paulo, pp 57-77.

Iskandar, H.M.; Casu, R.E.; Fletcher, A.T.; Schmidt, S.; Xu, J.; Maclean, D.J.; Manners, J.M. \& Bonnett, G.D. (2011). Identification of Drought Response Genes and a Study of Their Expression During Sucrose Accumulation and Water Deficit in Sugarcane Culms. BMC Plant Biology, Vol.11, (January 2011), pp. 12, ISSN 1471-2229.

Jackson, P.A. (2005). Breeding for Improved Sugar Content in Sugarcane. Field Crops Research, Vol.92, No.2-3, (June 2005), pp. 277-290, ISSN 0378-4290.

Jagtap, R. A., Tawar, P. N. Sen. D. R, Pant, N. M. and Hapase, D.G. (1992). Physio-Anatomical studies in sugarcane varieties and their somaclones grown under water stress conditions. Plant Physio \& Biochem. 19(1):42-48.
Karakas, B., Ozias, A. P., Stushnoff, C., Suefferheld, M. and Rieger, M. (1997). Salinity and drought tolerance of mannitol-accumulating transgenic tobacco. Plant Cell and Environment 20:609-616.

Khan, M. S.; Yadav,S.; Srivastava,S.; Swapna, M.; Chandra, A. \& Singh, R. K. (2011). Development and Utilization of Conserved Intron Scanning Marker in Sugarcane. Australian Journal of Botany, Vol.59, No.1, (February 2011), pp. 38-45, ISSN 0067-1924.

Kholovoda, V. P., V. V. Urmant seva and A. B. Meshcheryakov (1985). Sugar beet tissue culture as a model for studing physiological and biochemical processes. In : Plant cell culture (Edited by R. G. Butenko). 51-75 publishers corr. Merr.USSR Acad. Sci. Moscow.

Kwon-Ndung E. H. and E.D. Imolehin (2007). Evaluation of sugarcane seedlings from biparental crosses using different growth substrates. African Crop Science Conference Proceedings Vol. 8. pp. 139-142.

Li, Y.R. and Zhou, K.Y. (1991). Prediction of sugarcane yield and quality from biochemical parameters in leaves of young shoots. Sugar Cane 1: 12-15.

Liu, G.F.; Zhou, H.K.; Zhu, Z.H.; Xu, H.M. \& Yang, J. (2007). Genetic Analysis for Brix Weight per Stool and Its Component Traits in Sugarcane (Saccharum officinarum). Journal of Zheijang University Science B, Vol.8, No.12, (December 2007), pp. 860-866, ISSN 1673-1581

Lu, Y. H.; A, D, Hont; D. I. T. Walker; P. S. Rao; P. Feldmannand and Glaszmann (1994). Relationships among ancestrai species of sugar cane revealed with RFLP using ingle copy maize nuclear probes. Euphytica 78: 718.

Lowry, O. H., Rooebrough, N. T., Farr, A. L. and Randall, R. J. (1951). Protein measurment with the polin phenol. J. Bio. Chen. 193: 265-275.

Maliga, P. (1984). Isolation and characterization of mutants in plant cell culture., Annu. Rev. Plant. Physiol., 35:519-542.

Madan, V.K., Singh, K., Soni, N., Nigam, M. and Saxena, Y.R. (1988). Foliar amylase, amylose, amylopectin and Starch patterns during growth and development of sugarcane. Sugar Cane 1:14-16.

Menossi, M.; Silva-Filho M.C.; Vincentz, M.; Van-Sluys, M.A. \& Souza, G.M. (2008). Sugarcane Functional Genomics: Gene Discovery for Agronomic Trait Development. International Journal of Plant Genomics, Vol.2008, (December 2007), pp. 458732, ISSN 16875370.

Milligan, S.B.; Gravois, K.A.; Bischoff, K.P. \& Martin, F.A. (1990). Crop Effects on Genetic Relationships Among Sugarcane Traits. Crop Science, Vol.30, No.4, (April 2004), pp. 927-931, ISSN 0011-183X.

Moore, P. H. (2005). Integration of Sucrose Accumulation Processes Across Hierarchical Scales: Towards Developing an Understanding of the Gene-to-Crop Continuum. Field Crops Research, Vol.92, pp. 119-135, ISSN 0378-4290. 
Mu-Qing, Z. and Ru-Kai, C. (1998). Osmotic adujstment in lives of sugarcane in response to water stress. Sugar Cane $5: 3-7$.

Nose, A., Uchara, M. and Kawamitsu, Y. (1994). Variation in leaf gas exchange traits of Saccharum including feral sugarcane, Saccharum spontaneum L. Japanese Journal of Crop Science 63:489-495.

Ortega, D.E., Pardo, J. and Morgado, G.A. (1984). Metabolic changes in sugarcane plants subjected to water stress. Journal Giencia deLa Agricultura 21:37-43.

Papini-Terzi, F. S.; Rocha, F. R.; Vêncio, R. Z. N.; Felix, J. M.; Branco, D. S.; Waclawovsky, A. J.; Del Bem, L. E. V.; Lembke, C. G.; Costa, M. D. L.; Nishiyama Jr, M. Y.; Vicentini, R.; Vincentz, M. G. A.; Ulian, E. C.; Menossi, M. \& Souza, G. M. (2009). Sugarcane Genes Associated with Sucrose Contente. BMC Genomics, Vol.10, No.120, (March 2009), pp. 120, ISSN 1471-2164.

Papini-Terzi, F.S.; Rocha, F.R.; Vêncio, R.Z.; Oliveira, K.C.; Felix, J. de M.; Vicentini, R.; Rocha, C. de S.; Simes, A.C.; Ulian, E.C.; di Mauro, S.M.; da Silva, A.M.; Pereira, C.A.; Menossi, M. \& Souza, G.M. (2005). Transcription Profiling of Signal Transduction-Related Genes in Sugarcane Tissues. DNA Research, Vol.12, No.1, pp. 27-38, ISSN 1340-2838.

Parida, S.K.; Pandit, A.; Gaikwad, K.; Sharma, T.R.; Srivastava, P.S.; Singh, N.K. \& Mohapatra, T. (2010). Functionally Relevant Microsatellites in Sugarcane Unigenes. BMC Plant Biology, Vol.10, (November 2010), pp. 251, ISSN 1471-2229.

Rai, R.K. (1999). Variation of epicuticular, wax content in sugar cane varieties and four species of Saccharum: a possible significance Cooperative - Sugar, 30(10):955957.

Sanjay Kumar and Devendra Kumar (2012). Genetic divergence in sugarcane Germplasm under sub-tropics. Scholarly Journal of Agricultural Science Vol. 2(8), pp. 186-189,

Seehy, M. A.; M. Moussa and E. A. Badr (1984). Induction of reverse mutation in waxy locus of Zea mays pollen grains by pesticides. Egypt. J. Genet. Cytol., 13: 137-142.
Sneath, P. H.A. (1976). Some applications of numerical taxonomy to plant breeding-Z. Pflanzenzuecht, 76:19 - 45.

Spang , H.A. and Platt, H. S. (1972). The effect of plant growth sybstances on the hyperchrmicity of DNA. Physical. Plant. 27: 321-326.

Sreenivasan T. V., B. S. Ahloowalia \& D. J. Heinz (1987). cytogenetic. In D. J. Heinz (Ed). Sugar cane improvement through breeding. Elsevier press. Amsterdam. Pp 211-253.

Swapna, M.; Sivaraju, K.; Sharma, R. K.; Singh, N. K. \& Mohapatra, T. (2010). Single-Strand Conformational Polymorphism of EST-SSRs: a Potential Tool for Diversity Analysis and Varietal Identification in Sugarcane. Plant Molecular Biology Reports, Vol.5, pp. 254-263, ISSN 0735-9640.

Swapna Simon and Hemaprabha G. (2010). Identification of two new drought specific candidate genes in sugarcane (Saccharum spp.). Electronic Journal of Plant Breeding, 1(4):1164-1170.

Tabasum, S.; Khan, F.A.; Nawaz, S.; Iqbal, M.Z. \& Saeed, A. (2010). DNA Profiling of Sugarcane Genotypes Using Randomly Amplified Polymorphic DNA. Genetics and Molecular Research, Vol.9, No.1, pp. 471-483, ISSN 1676-5680.

Vettore, A.L.; da Silva, F.R.; Kemper, E.L.; et al. (2003). Analysis and Functional Annotation of an Expressed Sequence Tag Collection for Tropical Crop Sugarcane. Genome Research, Vol.13, No.12, (November 2003), pp. 2725-2735, ISSN 1088-9051.

Waclawovsky, A.J.; Sato, P.M.; Lembke, C.G.; Moore, P.H. \& Souza, G.M. (2010). Sugarcane for Bioenergy Production: An Assessment of Yield and Regulation of Sucrose Content. Plant Biotechnology Journal, Vol.8, No.3, (April 2010), pp. 263-276, ISSN 1467-7644.

Wang, J.; Roe, B.; Macmil, S.; Yu, Q.; Jan, E.; Murray, J.E.; Tang, G.; Chen, C.; Najar, F.; Wiley, G.; Bower, J.; Van Sluys, M.A.; Rokhsar, D.S.; Hudson, M.E.; Moose, S.P.; Paterson, A.H. \& Ming, R. (2010). Microcollinearity Between Autopolyploid Sugarcane and Diploid Sorghum Genomes. BMC Genomics, Vol.11, pp. 261, ISSN 14712164.

Whitehouse, R. N. H. (1969). An application of canonical analysis plant breeding. Geet. Agrar. 23: 61-69. 


\section{الملخص العربي}

\section{الخواص الفيزيوكيماوية للكروماتين واستحداث تضاعفات فى قصب السكر}

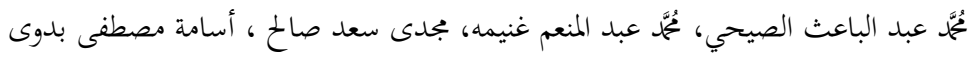

اللاهستونية وتقـدير درجـة حرارة إنصهار الكرومـاتين وكذلك DNA (nm 260

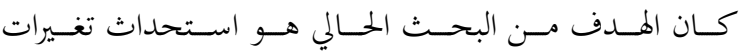
كروموسومية (تضاعف) للهيئة الكروموسومية الخاصة بجينوم نبات

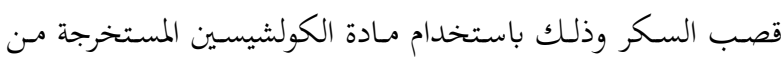
وكذلك تم تقدير بعض الصفات المحصوليه مثل المواد الصلبة الكلية وقياس متوسط أطوال النباتات وكذلك قيـاس متوسط قطر سيقان النباتات وفيما يلي ملخصا لأهم النتائج التي تم الحصول عليها: تمكن فئن

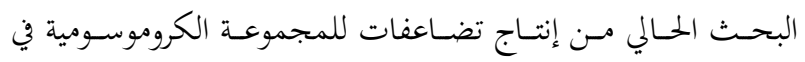
الصنف C9 بمتوسط 9 في المئة وفي الصنف PH 8013 بمتوسط 4 في لئ

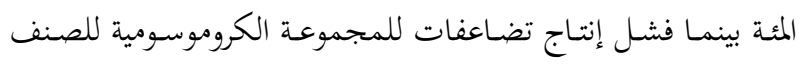
NCO 310 . وتراوح عدد البلاستيدات الخضراء في الخلايا الحارسة

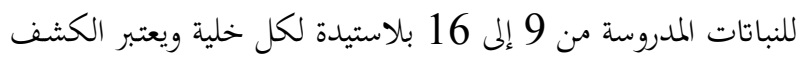
المبكر باستخدام الخـلايا الحارسة للثغور (عدد البلاستيدات) وسيلة

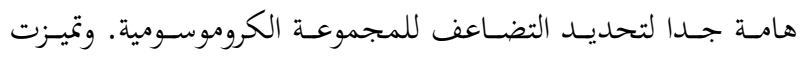
النباتات المتضاعفة بكبر حجم الحلايا وبطء النمو وكبر حجم الحزم

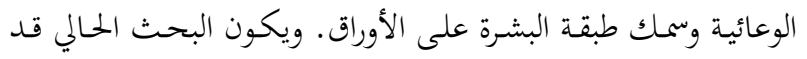
نجح في إنتاج نباتات متضاعفة من الصنف C9 وكذلك PH8013 إلا

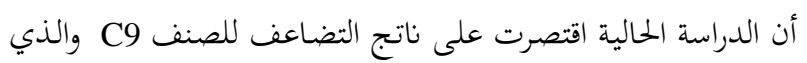
ثم إكثاره لتقيم باقي الخواص المحصولية لمذا الصنف. لئ. وبدراسة الاختلافات في التركيب الكيميائي ودرجة حرارة الانصهار

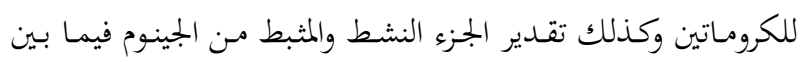

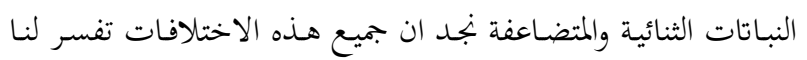
اختلاف النشاط النسخي بين هذه النباتات.

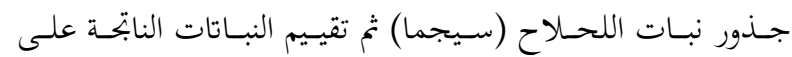
مستوى الوراثة الجزيئية للتنبؤ بقدراتا المحصولية.

ولتحقيق هذا الغرض تم الحصول على نباتات تابعة لثلاثة أصناف

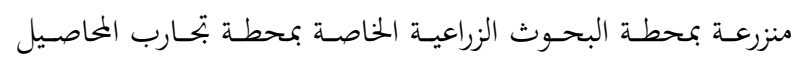

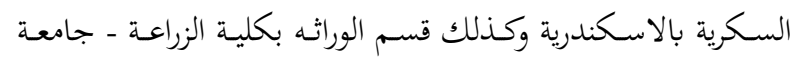
الاسكندرية وهذه الأصناف المنزرعة هي .8013 and NCO 310)

تم تقطيع السيقان إلي قطع صغيرة حسول منطقـة العقدـ لتحتوي

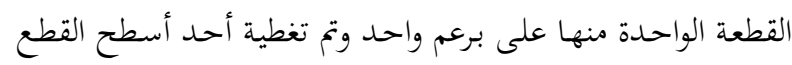
بطبقة من شمع البارافين بينما طَمر السطح الآخر في محلول 0.05

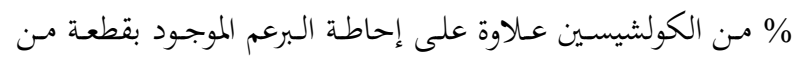

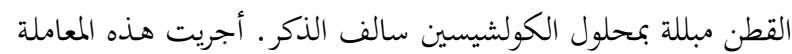
لمدة 7 أيام، تم استخدام قرابة 100 قطعة من كل صنف نقلت بعد مند

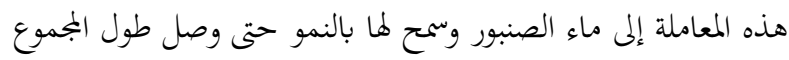

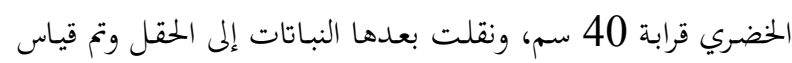

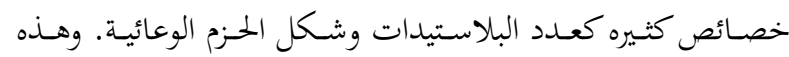
العوامل اعتبرت ككشاف أولي لتبع النباتات النامية.

تم دراسـة الخصـائص الفيزوكيماويـة للكرومـاتين وكـذلك الـ DNA المنزوع مـن أنويـة الأوراق مثل كميـة الـ DNA وتقديركمية البروتينـات

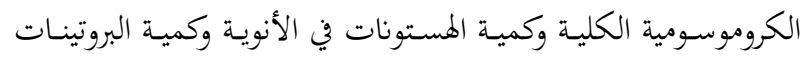

